\title{
Influence of Zinc and Iron Fortification on Yield and Post-Harvest Studies of Different Rice Cultivars (Oryza sativa L.)
}

\author{
S.R. Kadam*, V.M. Bhale, A.B. Chorey and M.R. Deshmukh \\ Dr. Panjabrao Deshmukh Krishi Vidhyapeeth, Akola (M.S), India \\ *Corresponding author
}

Keywords

Zinc, Iron,

Fortification, Post-

harvest studies and rice cultivars

Article Info

Accepted:

14 December 2017

Available Online:

10 January 2018

\section{A B S T R A C T}

Among the micronutrients, zinc deficiency is widespread throughout the world particularly in upland rice fields causing low yields and affecting nutritional quality of the produce. Iron is also another micronutrient which is lacking in soil as well as in human body. Field studies were carried out during the growing season 2015-16 and 2016-17 at Research Farm, Department of Agronomy, Dr. Panjabrao Deshmukh Krishi Vidyapeeth, Akola (Maharashtra) to study "Influence of zinc and iron fortification on yield and Post-harvest studies of different rice cultivars (Oryza sativa L.)". The treatments were laid out in factorial randomized block design (FRBD) with three replications. Two years results shows that among varieties PBNR-03-02 explored highest yield and post-harvest studies whereas combine application of $\mathrm{ZnSO}_{4}$ $+\mathrm{FeSO}_{4}$ with $\mathrm{RDF}$ treatment recorded maximum yield as well as post-harvest characters respectively.

\section{Introduction}

$\mathrm{Zn}$ and Fe deficiencies are widespread health problems. Iron deficiency is the most common nutritional disorder not only in the world, and almost 1.6 billion people are suffering from iron deficiency (De Benoist et al., 2008). Iron deficiency anemia is by far the most widespread micronutrient deficiency, and it results in impaired physical growth, mental development, and learning capacity (Bouis, 2003). Similarly, Zinc deficiency is equally serious and is ranked as the $5^{\text {th }}$ leading risk factor for diseases in the developing world (Maret and Sandstead, 2006). Numerous health problems link zinc deficiency to retarded growth, skeletal abnormalities, delayed wound healing, increased abortion risk, and diarrhea (Salgueiro et al., 2000). Approximately onethird of the world's population is suffering from zinc deficiency (Hotz and Brown, 2004). The situation is even more adverse in developing countries where more than half of the children and pregnant women are suffering from iron and zinc deficiencies (Seshadri, 2001). This situation is largely attributed to the high consumption of cereal based foods viz., rice (Oryza sativa L.), wheat (Triticum aestivum L.), and maize (Zea mays L.), in these countries (Pfeiffer and McClafferty, 2007). Edible parts (endosperms) of modern 
cereal cultivars are inherently poor in iron and zinc. The concentration of iron in the brown rice ranges from 6.3 to $24.4 \mathrm{mg} \mathrm{kg}^{-1}$ and zinc concentration ranges from 15.3 to $58.4 \mathrm{mg}$ $\mathrm{kg}^{-1}$ (Gregorio et al., 2000). However, polished rice, the principal form of rice consumed, on an average contains only $2 \mathrm{mg}$ $\mathrm{kg}^{-1}$ iron and $12 \mathrm{mg} \mathrm{kg}^{-1}$ zinc (Barry, 2006).

The existence of a negative relationship between irrigation and iron and zinc uptake (Scagel et al., 2012) and a similar negative relationship between phosphorus and iron and zinc uptake (Saha et al., 2013) also lead to lower the accumulation of these micronutrients in the cereal grains. Since the edible parts of the cereals are poor in iron and zinc, thus heavy dependence of people from developing countries on these foods results in the development of large-scale iron and zinc malnutrition. To alleviate iron and zinc deficiency, it is required to increase iron and zinc concentration in the endosperm to 8 and $30 \mathrm{mg} \mathrm{kg}{ }^{-1}$, respectively. Currently, there is growing concern to address micronutrient malnutrition through different interventions.

Typically, these interventions are categorized into 4 major groups: pharmaceutical supplementation, industrial fortification, dietary diversification, and biofortification (Meenaski et al., 2007).

In case of biofortification research efforts focused on development of high-yielding varieties and adoption of modern production technologies resulted in enhanced production leading to self-sufficiency in the country. Considering the all facts stated above, the present investigation entitled "Effect of zinc and iron fortification on growth and developmental stages of upland irrigated rice (Oryza sativa L.) cultivars" was planned with the objective to study the effect of Zinc and Iron on growth, yield and quality of upland rice cultivars.

\section{Materials and Methods}

Two field experiments were conducted at Research Farm, Department of Agronomy, Dr. Panjabrao Deshmukh Krishi Vidyapeeth, Akola (Maharashtra) during growing seasons 2015-16 and 2016-17. Texturally the soil was clay. It contained $8.6 \mathrm{pH}, 0.28 \mathrm{EC}, 0.52$ (g $\mathrm{kg}^{-1}$ ) organic carbon, $217.2 \mathrm{~kg} \mathrm{ha}^{-1}$ available $\mathrm{N}, 16.89 \mathrm{~kg} \mathrm{ha}^{-1}$ available $\mathrm{P}, 374.39 \mathrm{~kg} \mathrm{ha}^{-1}$ available $\mathrm{K}, 0.72 \mathrm{mg} \mathrm{kg}^{-1}$ available $\mathrm{Zn}, 9.01$ $\mathrm{mg} \mathrm{kg}^{-1}$ available Fe contents. The experiment was arranged in a factorial randomized block design with three replications, each plot being $3.6 \mathrm{~m} \mathrm{x} 4 \mathrm{~m}$. Sowing of upland irrigated rice was done on $31^{\text {st }}$ July 2015 during first year and on $26^{\text {th }}$ June 2017 during second year by drilling seeds per hill on $30 X 10 \mathrm{~cm}$.

Experiment consist of two factors namely varieties and nutrients. Varieties were consisted of three varieties viz., V1Sindewahi-1 (SYE-1), V2- Sindewahi-2001 (SYE-2001), V3- PBNR-03-02 and treatments were N1-RDF, N2- RDF + $\mathrm{ZnSO}_{4}\left(25 \mathrm{~kg} \mathrm{ha}^{-}\right.$ $\left.{ }^{1}\right), \mathrm{N}_{3}-\mathrm{RDF}+\mathrm{FeSO}_{4}\left(30 \mathrm{~kg} \mathrm{ha}^{-1}\right), \mathrm{N}_{4}-\mathrm{RDF}+$ Foliar spray of $\mathrm{ZnSO}_{4} @ 0.5 \%$ at flowering and dough stage, $\mathrm{N}_{5}-\mathrm{RDF}+$ Foliar spray of $\mathrm{FeSO}_{4} @ 1.0 \%$ at flowering and dough stage, $\mathrm{N}_{6}-\mathrm{RDF}+\mathrm{ZnSO}_{4}+\mathrm{FeSO}_{4}\left(25+30 \mathrm{~kg} \mathrm{ha}^{-1}\right)$. Five plants were selected from each plot at random.

Each plant marked with a small plastic white coloured ring and with wooden peg nearby for demarkation. The same five plants were observed at various stages of crop growth up to harvest for biometric observations. These five plants were harvested separately for postharvest observations.

\section{Results and Discussion}

The results obtained from the present investigation have been presented under following heads. 


\section{Yield characteristics}

\section{Grain yield $\left(\mathrm{kg} \mathrm{ha}^{-1}\right)$}

\section{Effect of varieties}

The average of two years shows pooled results of yield during both consecutive years. PBNR03-02 explored maximum yield and found significant over both the varieties whereas variety Sindewahi-1 has produced significantly more yield than Sindewahi-2001. Higher number of panicles $\mathrm{m}^{-2}$, LAI, dry matter and grains panicle ${ }^{-1}$ this was attributed mainly to major yield attributes mostly. Similar.results were achieved by Kusutani et al., (2000) and Dutta et al., (2002) who reported that genotypes producing higher number of effective tillers produced more grain yields in rice. PBNR-03-2 was the most efficient variety for conversion of biomass towards economic parts. Higher yields can be obtained by physiological process involving high accumulation of photosynthates and their partitioning (Miah et al., 1996).

\section{Effect of nutrients}

From pooled means of seed yield, Increase in yield it is apparent that application of $\mathrm{ZnSO}_{4}+$ $\mathrm{FeSO}_{4}$ with RDF posed a great increment in yield $\left(3072 \mathrm{~kg} \mathrm{ha}^{-1}\right)$ over rest of the treatments. The next best treatment obviously was that of alone application of $\mathrm{FeSO}_{4}$ with $\mathrm{RDF}$, which by recording $2867 \mathrm{~kg} \mathrm{ha}^{-1}$ yield over alone application of $\mathrm{ZnSO}_{4}$ with $\mathrm{RDF}$ ranked second. While foliar application of $\mathrm{FeSO}_{4} @ 1.0 \%$ with RDF registered marginally higher yield as compared to foliar application of $\mathrm{ZnSO}_{4} @ 0.5 \%$ with $\mathrm{RDF}$ and $\mathrm{RDF}$ alone. The contribution of $\mathrm{ZnSO}_{4}$ to increase yield was $12 \%$ and $\mathrm{FeSO}_{4} 6 \%$. Combine application of $\mathrm{Zn}+\mathrm{Fe}$ resulted in 34 $\%$ over RDF indicating essentiality of these nutrients in the initial year and in next year $\mathrm{ZnSO}_{4}$ increase yield $8 \%$ and $\mathrm{FeSO}_{4}$ increases by $6 \%$ and combination of $\mathrm{Zn}$ and $\mathrm{Fe}$ with RDF posed $28 \%$ increase in yield.

Increase in yield by combining micronutrients with $\mathrm{RDF}, \mathrm{N}$ increases vegetative growth, more synthesis of carbohydrates and their chloroplast the results are substantiated by the findings of the study Mattas et al., (2011) and Roshan et al., (2011). Similarly, the increase in grain yield on zinc addition might be due to enhanced formation of growth hormones such as auxin. Further, it also promotes starch formation and seed maturation. Similar findings were reported by Keram et al., (2012).

\section{Interaction effect}

Interaction effect of varieties and nutrients could not reach to the level of significance for Grain yield $\left(\mathrm{kg} \mathrm{ha}^{-1}\right)$.

\section{Straw yield $\left(\mathrm{kg} \mathrm{ha}^{-1}\right)$}

\section{Effect of varieties}

Pooled means of straw yield omitted that maximum straw yield was explored by PBNR03-02 by super sending rest of the two varieties. Sindewahi-2001 produced significantly more straw then Sindewahi-1. This may be due to genetic variability of varieties.

It may be attributed to higher dry matter accumulation. Variability among different rice varieties for straw was also noticed by Hari Om et al., (1997); Singh et al., (2000) and Suresh et al., (2001).

\section{Effect of nutrients}

As far as pooled values of straw yield concerned, the influence of treatments more amplified. Significantly highest straw yield was noted by the $\mathrm{ZnSO}_{4}+\mathrm{FeSO}_{4}$ with $\mathrm{RDF}$ 
over all the other treatments. Alone soil application of $\mathrm{FeSO}_{4}$ along with $\mathrm{RDF}$ shows slightly lesser straw yield but being par with the $\mathrm{ZnSO}_{4}$ with $\mathrm{RDF}$, least value of straw yield was observed in foliar application of $\mathrm{FeSO}_{4}$ and $\mathrm{ZnSO}_{4}$ with $\mathrm{RDF}$ and also with RDF alone.

Such an effects of micronutrients (Zn) application might be due to their critical role in crop growth, involving in photosynthesis process, respiration and biochemical and physiological activates and their importance in higher yield and biomass production, Zeidan et al., (2010).

\section{Interaction effect}

During both the year Interaction effect of varieties and nutrients was found to be significant.

\section{Biological yield $\left(\mathrm{kg} \mathrm{ha}^{-1}\right)$}

\section{Effect of varieties}

The biological yield of rice was significantly affected by different varieties. Maximum biological yield $\left(6012 \mathrm{~kg} \mathrm{ha}^{-1}\right.$ and $7788 \mathrm{~kg}$ $\mathrm{ha}^{-1}$ ) was obtained by variety PBNR-03-02 during 2015-16 and 2016-17 which was significantly superior over variety SYE-2001 $\left(\mathrm{V}_{2}\right)$ and statistically similar with the variety SYE-1 $\left(\mathrm{V}_{1}\right)$ (5549 and $\left.7520 \mathrm{~kg} \mathrm{ha}^{-1}\right)$. From the result it was observed that biological yield differed due to combined effect of grain yield and straw yield. Variability among different rice varieties for biological yield was also noticed by Laza et al., (2004); Singh et al., (2007); Lack et al., (2012) and Khalifa et al., (2014).

\section{Effect of nutrients}

When the production of the plant is supported by macro and micronutrient application, then certainly the reproductive capacity of plant enhances as par excellence. Such is the case with soil application of $\mathrm{ZnSO}_{4}+\mathrm{FeSO}_{4}$ with $\mathrm{RDF}$, where there was no barrier in supplying adequate nutrient to the plant had achieved overwhelming growth rate reflecting in attaining the greatest biological yield, when compared with remaining treatments. The soil application of $\mathrm{FeSO}_{4} 30 \mathrm{~kg} \mathrm{ha}^{-1}$ (6246 and $7912 \mathrm{~kg} \mathrm{ha}^{-1}$ ) was found at par with RDF + $\mathrm{ZnSO}_{4}\left(5404\right.$ and $\left.7785 \mathrm{~kg} \mathrm{ha}^{-1}\right)$. As evident in other characters maximum biological yield was noticed with addition of $\mathrm{Zn}$ and $\mathrm{FeSO}_{4}$ with RDF indicating the essentiality of these nutrients in this region.

$\mathrm{Zn}$, Fe and NPK manipulate the growth of rice, resulting in beneficial changes in yield and yield components. The possible reason for such beneficial role is the increase in the activity of growth hormone or activity of phosynthetic system or might be due to the active role of these micronutrients in metabolic processes of plants and photosynthesis and thus, tended to increase leaves formation, vegetative growth and grain formation which ultimately increased the yield attributes. These results are in line with that reported by Ananda and Patil (2005).

\section{Interaction effect}

Biological yield of both the respective year was not found significant.

\section{Harvest index (\%)}

\section{Effect of varieties}

The highest harvest index (46.13 and 45.97\%) was noticed by variety Sindewahi-2001 as compared to the other varieties during 201516 and 2016-17 whereas lowest harvest index was recorded by the variety Sindewahi-1 was (33.76 and 43.94\%). PBNR-03-02 and Sindewahi-1 produce lower harvest index 
because of emergence of new shoots from nodes before harvesting which contributed only towards straw yield. Superiority of PBNR-03-02 over other varieties indicated that this variety have efficient partitioning for assimilates of photosynthesis from source to sink (panicle). Laza et al., (2004), Singh et al., (2007) and Lack et al., (2012) also reported varietals differences for harvest index.

\section{Effect of nutrients}

Perusal of data in Table 1 indicated that harvest index is concerned, it have merely brought out the status of economic yield attained when compared with aggregate yield of grain and straw in case of rice. Among the treatments highest harvest index $(43.24 \%)$ was recorded by $\mathrm{RDF}+\mathrm{ZnSO}_{4}+\mathrm{FeSO}_{4}(25+30 \mathrm{~kg}$ $\mathrm{ha}^{-1}$ ) during 2016-17 ensures higher economic productivity from the respective treatment. Individual application of $\mathrm{ZnSO}_{4}$ and $\mathrm{FeSO}_{4}$ also produced higher $\mathrm{HI}$ indicating beneficial effect to converts photosynthates in to economic yield.

This might be occurred due to relative grain and straw yield of crop. On the contrary application of zinc increased harvest index, may be due to maximum dry matter partitioning towards grain, hence the grain yield was more by the application of zinc. Similarly, Ghaffari et al., (2011) reported increase in the harvest index of maize due to application of zinc. Iron helps in utilization of nitrogen. All these physiological processes proved instrumental in increasing $\mathrm{HI}$ by increasing yield as well as biomass, Ram et al., (2013).

\section{Post-harvest studies}

\section{Number of panicles plant ${ }^{-1}$}

Number of panicles plant ${ }^{-1}$ is an important character which directly influences grain yield of the crop. Data on Number of panicles plant $^{-1}$ under various treatments are enumerated in Table 19 which indicated that panicles were affected significantly due to genotypic variation and varietal management.

\section{Effect of varieties}

Number of panicles plant ${ }^{-1}$ indicated that among the varieties variety PBNR-03-02 has produced maximum number of panicles plant ${ }^{-1}$ (5.23 and 6.28) which was statistically similar with the SYE-1 during both the years and found significantly higher than variety SYE2001.

Whereas variety SYE-2001 was having lowest number of panicle (4.42 and 5.52) may be due to lowest numbers of tillers in both the years which supported by the research conducted by the Hossain et al., (2008) who reported.

Similar results that number of panicles depends on number of tillers and proportion of effective tillers to that particular variety.

\section{Effect of nutrients}

Data regarding Number of panicles plant ${ }^{-1}$ shows that the maximum number of panicle plant $^{-1}$ (5.47 and 6.62) were produced with an combine application of $\mathrm{ZnSO}_{4}+\mathrm{FeSO}_{4}$ with $\mathrm{RDF}$ which were comparable with alone application $\mathrm{ZnSO}_{4}$ and $\mathrm{FeSO}_{4}$ applied either soil and foliar spray but found superior over RDF.

It was further observed that the number of panicles was increased due to addition of $\mathrm{FeSO}_{4}$ and $\mathrm{ZnSO}_{4}$.

The foliar application of these nutrients were also responsible to increase the number of panicles per plant indicating the role of zinc and ferrous. Similar results were observed during the second year of experimentation. 
Table.1 Grain yield $\left(\mathrm{kg} \mathrm{ha}^{-1}\right)$, Biological yield $\left(\mathrm{kg} \mathrm{ha}^{-1}\right)$, straw yield $\left(\mathrm{kg} \mathrm{ha}^{-1}\right)$ and harvest Index $(\%)$ of upland irrigated rice cultivars as influenced by different treatments during 2015-16 and 2016-17

\begin{tabular}{|c|c|c|c|c|c|c|c|c|c|c|c|}
\hline \multirow[t]{2}{*}{ Treatments } & \multicolumn{3}{|c|}{ Grain yield (kg ha $\left.{ }^{-1}\right)$} & \multicolumn{3}{|c|}{ Straw yield $\left(\mathrm{kg} \mathrm{ha}^{-1}\right)$} & \multicolumn{2}{|c|}{ Biological yield ( $\mathrm{kg} \mathrm{ha}^{-1}$ ) } & \multicolumn{3}{|c|}{ Harvest index \% } \\
\hline & $\begin{array}{l}15- \\
16\end{array}$ & $\begin{array}{l}16- \\
17\end{array}$ & Pooled & $15-16$ & 16-17 & Pooled & $15-16$ & 16-17 & $15-16$ & 16-17 & Pooled \\
\hline \multicolumn{12}{|l|}{ A) Varieties (V) } \\
\hline $\begin{array}{ll}V_{1}- & \text { Sindewahi -1 (SYE-1) } \\
\end{array}$ & 1771 & 3276 & 2523 & 3778 & 4175 & 3575 & 5549 & 7520 & 33.76 & 43.94 & 38.84 \\
\hline $\begin{array}{lll}V_{2}- & \text { Sindewahi-2001 } \\
2001)\end{array}$ & 1601 & 3140 & 2370 & 2105 & 3734 & 2630 & 3707 & 6873 & 46.13 & 45.97 & 46.21 \\
\hline $\begin{array}{ll}V_{3}- & \text { PBNR-03-02 } \\
\end{array}$ & 2233 & 3613 & 2923 & 4060 & 4342 & 3736 & 6293 & 7788 & 38.88 & 45.87 & 41.61 \\
\hline $\mathrm{SE}(\mathrm{m})+$ & 49 & 83 & 34 & 343 & 122 & 22 & 343 & 145 & - & - & - \\
\hline $\mathrm{CD}(\mathrm{P}=0.05)$ & 135 & 230 & 103 & 951 & 338 & 66 & 951 & 403 & - & - & - \\
\hline \multicolumn{12}{|l|}{ B) Nutrients (N) } \\
\hline $\begin{array}{l}\mathrm{N}_{1-} \\
\left.\mathrm{ha}^{-1}\right)\end{array}$ RDF (100: 50:50 NPK kg & 1494 & 2775 & 2134 & 2107 & 3395 & 2472 & 3601 & 6170 & 43.24 & 44.97 & 44.09 \\
\hline $\mathrm{N}_{2}-\quad \mathrm{RDF}+\mathrm{ZnSO}_{4}\left(25 \mathrm{~kg} \mathrm{ha}^{-1}\right)$ & 1985 & 3584 & 2784 & 3419 & 4201 & 3427 & 5404 & 7785 & 39.75 & 45.97 & 42.85 \\
\hline $\mathrm{N}_{3}-\quad \mathrm{RDF}+\mathrm{FeSO}_{4}\left(30 \mathrm{~kg} \mathrm{ha}^{-1}\right)$ & 2126 & 3609 & 2867 & 4120 & 4304 & 3788 & 6246 & 7912 & 38.28 & 45.87 & 42.07 \\
\hline $\begin{array}{l}\mathrm{N}_{4^{-}} \quad \mathrm{RDF}+\text { Foliar spray of } \\
\mathrm{ZnSO}_{4} @ 0.5 \% \text { at flowering and } \\
\text { dough stage }\end{array}$ & 1593 & 2977 & 2284 & 2752 & 3846 & 2996 & 4344 & 6823 & 38.74 & 43.78 & 41.26 \\
\hline $\begin{array}{l}\mathrm{N}_{5}-\mathrm{RDF}+\quad \text { Foliar spray of } \\
\mathrm{FeSO}_{4} @ 1.0 \% \text { at flowering and } \\
\text { dough stage }\end{array}$ & 1748 & 3232 & 2490 & 3206 & 4191 & 3327 & 4955 & 7423 & 39.71 & 43.84 & 41.76 \\
\hline $\begin{array}{l}\mathrm{N}_{6}- \\
\mathrm{FeSO}_{4}\left(25+30 \mathrm{~kg} \mathrm{ha}^{-1}\right)\end{array}$ & 2265 & 3880 & 3072 & 4282 & 4366 & 3900 & 6547 & 8246 & 37.80 & 47.14 & 42.47 \\
\hline $\mathrm{SE}(\mathrm{m}) \pm$ & 69 & 117 & 49 & 485.3 & 173 & 38 & 485 & 205 & - & - & - \\
\hline $\mathrm{CD}(\mathrm{P}=0.05)$ & 192 & 325 & 146 & 1345. & 479 & 93 & 1345 & 570 & - & - & - \\
\hline \multicolumn{12}{|l|}{ C) Interactions ( $\mathbf{~ x ~ N )}$} \\
\hline $\mathrm{SE}(\mathrm{m}) \pm$ & 120 & 203 & 85 & 840 & 299 & 54 & 840 & 356 & - & - & - \\
\hline $\mathrm{CD}(\mathrm{P}=0.05)$ & NS & NS & NS & NS & NS & NS & NS & NS & - & - & - \\
\hline General Mean & 1868 & 3343 & 2605 & 3314 & 4119 & 3313 & 5183 & 7394 & 39.71 & 45.26 & 42.42 \\
\hline
\end{tabular}




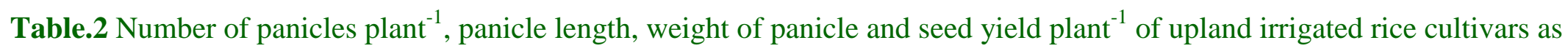
influenced by different treatments during 2015-16 and 2016-17

\begin{tabular}{|c|c|c|c|c|c|c|c|c|}
\hline \multirow[t]{2}{*}{ Treatments } & \multicolumn{4}{|c|}{ 2015-16 } & \multicolumn{4}{|c|}{ 2016-17 } \\
\hline & $\begin{array}{c}\text { Number } \\
\text { of } \\
\text { panicles } \\
\text { plant }^{-1}\end{array}$ & $\begin{array}{c}\text { Panicle } \\
\text { length } \\
\text { (cm) }\end{array}$ & $\begin{array}{l}\text { Weight of } \\
\text { panicle }(g)\end{array}$ & $\begin{array}{c}\text { Seed } \\
\text { yield } \\
\text { plant }^{-1}(\mathrm{~g})\end{array}$ & $\begin{array}{c}\text { Number } \\
\text { of } \\
\text { panicles } \\
\text { plant }^{-1}\end{array}$ & $\begin{array}{c}\text { Panicle } \\
\text { length } \\
\text { (cm) }\end{array}$ & $\begin{array}{l}\text { Weight } \\
\text { of } \\
\text { panicle } \\
\text { (g) }\end{array}$ & $\begin{array}{c}\text { Seed } \\
\text { yield } \\
\text { plant }^{-1}(\mathrm{~g})\end{array}$ \\
\hline \multicolumn{9}{|l|}{ A) Varieties (V) } \\
\hline $\begin{array}{ll}V_{1}- & \text { Sindewahi -1 (SYE-1) } \\
\end{array}$ & 4.92 & 14.18 & 2.79 & 8.59 & 5.96 & 15.25 & 3.76 & 13.55 \\
\hline $\mathrm{V}_{2}-\quad$ Sindewahi-2001 (SYE-2001) & 4.42 & 12.02 & 2.32 & 8.24 & 5.52 & 13.23 & 3.34 & 12.93 \\
\hline SE $(m) \pm$ & 0.16 & 0.49 & 0.29 & 0.18 & 0.20 & 0.23 & 0.11 & 0.35 \\
\hline $\mathrm{CD}(\mathrm{P}=0.05)$ & 0.45 & 1.37 & 0.82 & 0.51 & 0.57 & 0.79 & 0.32 & 0.98 \\
\hline \multicolumn{9}{|l|}{ B) Nutrients (N) } \\
\hline $\mathrm{N}_{1}-\quad$ RDF (100: 50:50 NPK kg ha $)$ & 4.43 & 13.84 & 2.26 & 6.76 & 5.58 & 15.19 & 3.76 & 10.33 \\
\hline $\mathrm{N}_{2}-\quad \mathrm{RDF}+\mathrm{ZnSO}_{4}\left(25 \mathrm{~kg} \mathrm{ha}^{-1}\right)$ & 4.86 & 15.58 & 2.87 & 7.67 & 5.92 & 16.51 & 4.32 & 13.37 \\
\hline $\mathrm{N}_{3}-\quad \mathrm{RDF}+\mathrm{FeSO}_{4}\left(30 \mathrm{~kg} \mathrm{ha}^{-1}\right)$ & 5.03 & 15.96 & 3.58 & 10.74 & 6.32 & 16.53 & 4.48 & 16.03 \\
\hline $\begin{array}{l}\mathrm{N}_{5}-\mathrm{RDF}+\mathrm{Foliar} \text { spray of } \mathrm{FeSO}_{4} @ \\
1.0 \% \text { at flowering and dough stage }\end{array}$ & 4.84 & 15.56 & 2.82 & 7.50 & 5.63 & 16.01 & 4.18 & 12.35 \\
\hline $\begin{array}{l}\mathrm{N}_{6}-\mathrm{RDF}^{-} \mathrm{ZnSO}_{4}+\mathrm{FeSO}_{4}(25+30 \\
\left.\mathrm{kg} \mathrm{ha}^{-1}\right)\end{array}$ & 5.47 & 17.00 & 4.26 & 13.81 & 6.62 & 17.09 & 4.64 & 18.92 \\
\hline SE $(\mathbf{m}) \pm$ & 0.23 & 0.70 & 0.41 & 0.26 & 0.29 & 0.40 & 0.16 & 0.50 \\
\hline $\mathrm{CD}(\mathrm{P}=\mathbf{0 . 0 5})$ & 0.64 & 1.94 & 1.16 & 0.72 & 0.80 & 1.18 & 0.45 & 1.39 \\
\hline \multicolumn{9}{|l|}{ C) Interactions ( $\mathbf{V} \times \mathbf{N})$} \\
\hline $\mathrm{SE}(\mathrm{m}) \pm$ & 0.40 & 1.21 & 0.72 & 0.45 & 0.50 & 0.69 & 0.28 & 0.87 \\
\hline $\mathrm{CD}(\mathrm{P}=0.05)$ & 1.12 & NS & NS & NS & NS & NS & NS & NS \\
\hline General Mean & 4.86 & 15.43 & 3.04 & 8.93 & 5.92 & 16.21 & 4.23 & 13.70 \\
\hline
\end{tabular}


More number of panicles $\mathrm{m}^{-1}$ row, with combine application of RDF and micronutrients increase the use efficiency of added nutrients and supply it continuously to the plant throughout the crop growth period and promoted various physiological activities in plant which are consider being indispensable for proper growth and development. These results are in conformity with those of Nagrajan (1995) and Atwal et al., (1998).

\section{Interaction effect}

Effect of varieties and nutrient over panicles plant $^{-1}$ was found to be non-significant.

\section{Panicle length $(\mathrm{cm})$}

Length of Panicle is an important yield component, which affect the number of grains per spike. The data on length of panicle as influenced by various treatments have been presented in Table 2. Both varieties and levels of micronutrients had significant effect on panicle length during both the years of investigation.

\section{Effect of varieties}

Panicle length $(\mathrm{cm})$ was significantly influenced by affected by different varieties and mean length of variety PBNR-03-02 was 20.08 and $19.98 \mathrm{~cm}$ in 2015-16 and 2016-17 respectively whereas short panicle (12.02 and $13.23 \mathrm{~cm})$ length was recorded by the variety SYE-2001 $\left(\mathrm{V}_{2}\right)$.

The significantly more panicle length was observed in variety PBNR-03-02 than SYE2001, lowest panicle length was observed in Sindewahi-1. Sharma (2002) reported significant difference in panicle length among fine grain rice genotypes due to different nature in genotypic character.

\section{Effect of nutrients}

During both alternate years maximum panicle length $(17$ and $17.09 \mathrm{~cm})$ was recorded with combination of $\mathrm{ZnSO}_{4}, \mathrm{FeSO}_{4}$ along with the RDF which was found significantly superior over rest of the treatments. Soil application of $\mathrm{FeSO}_{4}$ along with $\mathrm{RDF}$ was found increasing panicle length than the RDF alone. $\mathrm{ZnSO}_{4}$ with $\mathrm{RDF}$ also responsible for increasing the panicle length. Beneficial effect of foliar spray of zinc and ferrous was also noticed. Combined application of $\mathrm{Zn}, \mathrm{Fe}$ and $\mathrm{RDF}$ increased the grains of panicle and length is depend upon the grain bearing capacity of panicle owing to better utilization of nutrients for grain production and length of panicle through metabolic activities. The present results are in agreement with the findings of Mehra and Shekhawat.

\section{Interaction effect}

Panicle length $(\mathrm{cm})$ was found non-significant over both the factors.

\section{Weight of panicle $(g)$}

\section{Effect of varieties}

During first year of experiment variety PBNR03-02 produce the maximum weight of panicle which was significantly higher than SYE-1 and SYE-2001. However the later varieties were on par with each other. During the second year of experimentation PBNR-03-02 produce maximum weight of panicle $(5.59 \mathrm{~g})$ which was significantly superior over SYE-1 also produce significantly more weight of panicle than the SYE-2001.

Cultivars with an extremely high number of tillers would have greater consumption of stored materials by excessively bigger sink size so, panicle weight automatically increased (Yoshida and Parao, 1976).

\section{Effect of nutrients}

During initial year maximum weight of panicle (4.26 and $4.64 \mathrm{~g})$ was observed with the addition of $\mathrm{ZnSO}_{4} 25 \mathrm{~kg}$ and $\mathrm{FeSO}_{4} 30 \mathrm{~kg} \mathrm{ha}^{-1}$ with RDF which was found significantly superior over rest of the treatments except soil 
application of $\mathrm{ZnSO}_{4}$ and highest weight of panicle (4.26 g) was recorded by the combine application of $\mathrm{ZnSO}_{4}$ and $\mathrm{FeSO}_{4}$ alone along with RDF.

Foliar application of $\mathrm{ZnSO}_{4}$ and $\mathrm{FeSO}_{4}$ along with RDF was responsible for increasing the weight of panicle indicating the essentiality of these nutrients in addition to RDF. Similar trend was observed during next year also.

The better effectiveness of mixed application of these micronutrients may be attributed to their synergism effect.

These findings are consistence with the previous researches that indicates combination of zinc with other elements improved the photosynthetic attributes and has a positive effect on reproductive organs to produce more grain Similar findings were reported by Patel (1999).

\section{Interaction effect}

Interaction effect of varieties and nutrients in respect to weight of panicle (g) of rice could not reach to the level of significance.

\section{Seed yield plant ${ }^{-1}$}

Generally the grain yield per unit area and number of grains spike- 1 are the most important determinants of the yield which are affected by various factors including balanced nutrition. As shown in Table 19, different varieties and micronutrients shows significant variation during 2015-16 and 2016-17.

\section{Effect of varieties}

Maximum seed yield plant ${ }^{-1}$ was observed with variety PBNR-03-02 (9.96 gm) which was significantly higher than other two varieties. The variety SYE-1 produce more seed yield as compared to SYE-2001. Similar result was also observed during second year of experimentation.
The varietal character of the Variety PBNR-0302 documented highest seed yield plant $^{-1}$ PBNR-03-02 variety well-adjusted to the conditions of Akola so they performed better while changing spikelets into grains as compared to other varieties.

\section{Effect of nutrients}

During 2015-16 application of $\mathrm{ZnSO}_{4}$ and $\mathrm{FeSO}_{4}$ with RDF recorded maximum seed yield plant $^{-1}$ which was significantly higher than the rest of the treatments alone application of $\mathrm{FeSO}_{4}$ produce maximum seed yield which was significantly superior over alone soil applied $\mathrm{ZnSO}_{4}$ along with RDF and also RDF alone. Foliar spray of either $\mathrm{ZnSO}_{4}$ or $\mathrm{FeSO}_{4}$ increase the seed yield compared with the recommended dose of fertilizer but not reached to the level of significance. Soil application of $\mathrm{FeSO}_{4}$ along with RDF significantly increase the seed yield than the alone application of $\mathrm{ZnSO}_{4}$ along with RDF this indicated that significance of $\mathrm{FeSO}_{4}$ can increasing productivity of rice. While comparing the addition of either $\mathrm{ZnSO}_{4}$ or $\mathrm{FeSO}_{4}$ in soil are foliar spray, the significance of soil application was more compared to foliar spray it was further observed that there is need to apply zinc and ferrous in addition to the RDF.

These findings are consistence with the previous researches that indicates combination of zinc with iron improved the photosynthetic attributes and has a positive effect on reproductive organs to produce more grain yield (Zayed, 2011) also flag leaf plays an important role in grain yield similar findings given by Patel et al., (1999).

\section{Interaction effect}

Effect of varieties and nutrients over seed yield plant $^{-1}$ was found to be non-significant. On the basis of the results obtained, the following conclusions of significant and utility can be drawn. Variety PBNR-03-2 recorded significantly higher yield and post-harvest characteristics. 
Soil application of RDF (100:50:50 $\left.\mathrm{kg} \mathrm{ha}^{-1}\right)+$ $\mathrm{ZnSO}_{4}\left(25 \mathrm{~kg} \mathrm{ha}^{-1}\right)+\mathrm{FeSO}_{4}\left(30 \mathrm{~kg} \mathrm{ha}^{-1}\right)$ recorded significantly highest yield and postharvest characters.

Maximum GMR, NMR and $\mathrm{B}$ : $\mathrm{C}$ ratio was recorded with upland rice cultivar PBNR-03-02 in combination with fertilizer treatment of RDF $\left(100: 50: 50 \mathrm{~kg} \mathrm{ha}^{-1}\right)+\mathrm{ZnSO}_{4}\left(25 \mathrm{~kg} \mathrm{ha}^{-1}\right)+$ $\mathrm{FeSO}_{4}\left(30 \mathrm{~kg} \mathrm{ha}^{-1}\right)$.

\section{References}

Ananda N and Patil BN 2005. Influence of zinc, iron and time of nitrogen application on growth, yield and quality of durum wheat. Karnataka Journal of Agricultural Science, 18 (3): 599-603

Atwal SS, Shantha Nagarajan, Sharma RK. and Nagarajan S 1998. Micronutrient in wheat seed quality and yield under rice-wheat system. Indian Wheat Newsletter, 4(2): 45.

Barry G. 2006. High-iron and -zinc rice. Available from: http://www.knowledgebank.irri.org/rkb/h ealth-and-nutrition/high-ironand-zincrice.html, IRRI. Accessed 2014 January 20.

Bouis HE 2003. Micronutrient fortification of plants through plant breeding can it improve nutrition in man at low cost. Proc. Nutri. Soc. May: 62 (2): 403-11

De Benoist B, Mclean E, Anderson M, Rogers L 2008. Iodine deficiency in 2007: global progress since 2003. Food Nutr. Bull. 2008 Sep. 29 (3): 195-202

Dutta, R.K., M.A. Baset Mia and S. Khanam 2002. Plant architecture and growth characteristics of fine grain and aromatic rices and their relation with grain yield. IRC Newsletter. 51: 51-56.

Ghaffari AA, Ali M, Tahir M, Waseem M, Ayub A, Iqbal and Mohsin AU. 2011. Influence of integrated nutrients on growth, yield and quality of maize (Zea mays L.). Am. J. Plant Sci. 2: 63-69

Gregorio GB 2002. Progress in breeding for trace minerals in staple crops. J. Nutr.
132:500-502

Hossain, M. B., M. O. Islam and M. Hasanuzzaman 2008. Influence of different nitrogen levels on the performance of four aromatic rice varieties. Int. J. Agric. Biol. 10: 693-696.

Hotz C, Brown KH 2004. International Zinc Nutrition Consultative Group (IZiNCG). Assessment of the risk of zinc deficiency in populations and options for its control. Food Nutr Bull 25:91-204

Keram KS, Sharma BL and Sawarkar SD. 2012. Impact of $\mathrm{Zn}$ application on yield, quality, nutrients uptake and soil fertility in a medium deep black soil (vertisol). International Journal of Science and Environment 1(5): 563-571.

Khalifa, A., Ali, A., ELkhoby, W. and Okasha, E.M. 2014. Effect of sowing dates and seed rates on some rice cultivars. African Journal of Agricultural Research 9(2): 196-201.

Lack, Shahram., Marani, Nasim Mahdian and Mombeni, Mehran 2012. The Effects of Planting Date on Grain Yield and Yield Components of Rice Cultivars. Advances in Environmental Biology 6(1): 406-413

Laza, R.C., Peng, S., Akita, S. and Saka, H. 2004. Effect of panicle size on grain yield of IRRI-released indica rice cultivars in the wet season. Plant Production Science. 73(3): 271-276.

Maret W, Sandstead H 2006. Zinc requirements and the risk and benefits of zinc supplementation. J. Trace Element Med Biol 20:3-18

Mattas KK, Uppal RS and Singh RP. 2011. Effect of varieties and nitrogen management on the growth, yield and nitrogen uptake of durum wheat. Research Journal of Agricultural Sciences 2(2): 376-380.

Meenakshi JV, Johnson N,Manyong VM, De Groote H, Javelosa J, Yanggen D, Naher F, Gonzalez C, Garcia J, Meng E. 2007. How cost effective is biofortification in combating micronutrient malnutrition? An ex-ante assessment. Harvest Plus 2007:188-209. 
Mehra RK and Shekhawat JS 1999. Effect of different levels of manganese, iron and soil typeson yield and zinc content of wheat (Triticum aestivum L.). Crop Research, 17 (1): 121-124.

Miah, M.N.H., T. Yoshida, Y. Yamamoto and Y. Nitta 1996. Characteristics of dry matter production and partitioning of dry matter to panicles in high yielding Semidwarf indica and Japonica indica hybrid rice varieties. Japanese J. Crop Sci. 65:672-685.

Patel JR 1999. Effect of levels and methods of nitrogen application on wheat yield. Journal of Maharashtra Agricultural Universities. 24(1): 108-109.

Pfeiffer WH, McClafferty B. HarvestPlus: breeding crops for better nutrition. Crop Science. 2007; 47: 88-105.

Ram H, Sohu VS, Singh, Cakmak K, Ismail, Buttar GS, Sodhi GPS, Gill HS, Bhagat, Indoo, Singh, Parminder, Dhaliwal SS and Mavi GS 2013. Agronomic fortification of rice and wheat grains for improving human health.

Roshan NM, Azarpour E and Moradi M. 2011. Study effects of different $\mathrm{N}$ and micronutrients fertilizer rates on yield and yield components of rice. World Applied Sciences Journal 13(3): 419-423.

Saha B, Saha S, Poddar P, Murmu S, Singh AK. 2013. Uptake of nutrients by wheat as influenced by long-term phosphorus fertilization. The Bioscan 8(4):1331-5.

Salgueiro MJ, Zubillaga M, lysionek A, Sarabia M, Caro R, Paoli TD, Hager A, Weill R, Boccaio J 2002. Zinc as an essential micronutrient: A Review, 20(5): 737-755

Scagel C, Bi G, Fuchigami L, Regan, R. 2012. Irrigation frequency alters nutrient uptake in container-grown Rhododendron plants grown with different rates of nitrogen.
Hort. Sci. 47(2):189-97.

Seshadri S 2001. Prevalence of micronutrient deficiency particularly of iron, zinc and folic acid in pregnant women in South East Asia. British Journal of Nutrition. 85, S87-S92.

Sharma, N. 2002. Quality characteristics of nonaromatic and aromatic rice (Oryza sativa L.) varieties of Punjab. Indian J. Agri. Sci. 72: 408-410.

Singh, H, Singh, KN and Hasan, B 2007. Evaluation of CERES rice model (V. 4.0) under temperate conditions of Kashmir valley, India. Cereal Research Communication 35:1723-1732.

Singh, MK, Thakur R, Verma, UN, Upasani, RR and Pal, SK 2000. Effect of planting time and nitrogen on production potential of basmati rice (Oryza sativa) cultivars in Bihar Plateau. Indian Journal of Agronomy 45(2): 300-303.

Suresh, KK, Ramamoorthy, K and Pandian, JSR 2001. Influence of sowing time and varieties on growth and yield of rainfed rice. Madras Agricultural Journal 88(1-3): 118-119.

Yoshida, S and Parao, FT 1976. Climatic influence on yield and yield components of lowland rice in the tropics. In Climate and rice. IRRI, Los Baños, Laguna, Philippines. 471-494

Zayed BA, Salem M, Sharkawy El. 2011. Effect of Different Micronutrient Treatments on Rice (Oryza sativa L.) Growth and Yield under Saline Soil Conditions. World Journal of Agricultural Sciences. 7: 179184.

Zeidan MS, Manal FM and Hamouda HA 2010. Effect of foliar fertilization of Fe, Mn and $\mathrm{Zn}$ on wheat yield and quality in low sandy soils fertility. World J. Agric. Sci. 6(6): 696-699.

\section{How to cite this article:}

Kadam, S.R., V.M. Bhale, A.B. Chorey and Deshmukh, M.R. 2018. Influence of Zinc and Iron Fortification on Yield and Post-Harvest Studies of Different Rice Cultivars (Oryza sativa L.). Int.J.Curr.Microbiol.App.Sci. 7(01): 1878-1888. doi: https://doi.org/10.20546/ijcmas.2018.701.226 